\title{
Childhood obesity and type 2 diabetes: the frightening epidemic
}

\author{
Nicola Santoro \\ New Haven, CT, USA
}

$\mathrm{T}$ The prevalence of childhood obesity is dramatically increasing worldwide. ${ }^{[1]}$ In 2010 about 35 million children were estimated to be overweight or obese, and this number is thought to double by $2020 .^{[1]}$ The increase of childhood obesity is accompanied by an increased prevalence of diseases once believed to be exclusive to adulthood, such as type 2 diabetes. ${ }^{[2]}$ Type 2 diabetes results from the imbalance between insulin secretion and resistance, therefore it typically occurs during puberty when there is a natural transient state of insulin resistance. ${ }^{[3]}$

Although type 2 diabetes in youth closely resembles type 2 diabetes in adults, it shows some peculiar characteristics. In particular, glucose dysregulation progresses toward overt diabetes faster in youths than in adults. In fact, while in adults the transition toward type 2 diabetes takes about 10 years with about 7\% reduction per year in beta cell function, ${ }^{[4,5]}$ in obese youth, the reduction of beta cell function occurs at a rate of about $15 \%$ per year, ${ }^{[6]}$ with a mean transition time from pre-diabetes to overt diabetes of about 2.5 years. ${ }^{[7]}$ Also, youths with type 2 diabetes seem to be resistant to pharmacological mono-therapy (with metformin or rosiglitazone) and to lifestyle intervention. ${ }^{[8]}$ The Treatment Options for Type 2 Diabetes in Adolescents and Youth (TODAY) study, a study involving several centers in the U.S., showed discouraging results. ${ }^{[8]}$ The TODAY study involved youth with type 2 diabetes and consisted of three arms: treatment with metformin alone, metformin plus lifestyle intervention, and metformin plus rosiglitazone; the endpoint was glycated hemoglobin

\footnotetext{
Author Affiliations: Department of Pediatrics, Yale University School of Medicine, New Haven, CT, USA (Santoro N)

Corresponding Author: Nicola Santoro, MD, PhD, Department of Pediatrics, Yale University School of Medicine, 330 Cedar Street, P.O. Box 208064, New Haven 06520, CT, USA (Tel: 203-737-6356; Fax: 203-7856421; Email: nicola.santoro@yale.edu)

doi: $10.1007 /$ s 12519-013-0410-8

CChildren's Hospital, Zhejiang University School of Medicine, China and Springer-Verlag Berlin Heidelberg 2013. All rights reserved.
}

level (HbA1c). Half of the patients receiving the treatment with metformin alone failed, metformin plus lifestyle intervention did not improve glycemic control, and although the treatment with rosiglitazone and metformin improved durable glycemic control, 39\% of the patients still had a failed treatment. ${ }^{[8]}$

Evidence from this multi-center study suggests that type 2 diabetes can be a one-way trip for most of our patients, which is why more efforts should be made to prevent this condition, with early intervention in obese children before the onset of pre-diabetes or type 2 diabetes. This consideration raises further questions: Which is the best treatment for childhood obesity? Is any weight management program effective in obese children? Some encouraging data derive from the Bright Bodies program (http://www.brightbodies.org), a lifestyle intervention program held in some schools in New Haven (CT) ${ }^{[9]}$ In particular, the program consists of exercise twice (50 minutes each) and classes of nutrition/behavior modification once (40 minutes each) per week. ${ }^{[9]}$ Data from a controlled randomized trial where participants were randomly assigned to either a control or weight management group (Bright Bodies Program) for 6 months showed that the Bright Bodies weight management program had beneficial effects on body composition and insulin resistance in overweight children that were sustained up to 12 months. ${ }^{[9]}$ Also, more recently, the same group showed that these weight changes can be sustained up to 24 months after intervention. ${ }^{[10]}$

These data clearly suggest that the most powerful weapon against non-complicated childhood obesity is lifestyle intervention. One major pitfall is to consider the lifestyle intervention only as a therapeutic approach, and this brings me to my final consideration. What we generically call lifestyle intervention (or lifestyle changes) simply means: increased physical activity, less sedentary life and better quality food. These three things should be easily available and accessible to everybody, but in a globalized world where inequality and poverty are the rule rather than the exception, childhood obesity is "the global health problem" and it needs to be solved from a political point of view as much as from a medical perspective. 
Funding: Santoro $\mathrm{N}$ is supported by the American Hearth Association (AHA) (11CRP5620013) and Yale Center for Clinical Investigation (YCCI) Scholar Award 2012. This publication was also made possible by CTSA Grant Number UL1 RR024139 from the National Center for Advancing Translational Science (NCATS), a component of the National Institutes of Health (NIH), and NIH roadmap for Medical Research. Its contents are solely the responsibility of the authors and do not necessarily represent the official view of NIH.

Ethical approval: Not needed.

Competing interest: None.

Contributors: Nicola Santoro conceived and wrote the manuscript.

\section{References}

1 de Onis M, Blössner M, Borghi E. Global prevalence and trends of overweight and obesity among preschool children. Am J Clin Nutr 2010;92:1257-1264.

2 Sinha R, Fisch G, Teague B, Tamborlane WV, Banyas B, Allen $\mathrm{K}$, et al. Prevalence of impaired glucose tolerance among children and adolescents with marked obesity. N Engl J Med 2002;346:802-810.

3 Caprio S, Plewe G, Diamond MP, Simonson DC, Boulware $\mathrm{SD}$, Sherwin RS, et al. Increased insulin secretion in puberty: a compensatory response to reductions in insulin sensitivity. $\mathrm{J}$
Pediatr 1989;114:963-967.

4 Kahn SE. The importance of $\beta$-cell failure in the development and progression of type 2 Diabetes. J Clin Endocrinol Metab 2001;86:4047-4058.

5 Matthews DR, Cull CA, Stratton IM, Holman RR, Turner RC. UKPDS 26: sulfonylurea failure in non-insulin dependent diabetic patients over six years. UK Prospective Diabetes Study (UKPDS) Group. Diabet Med 1998;15:297-303.

6 Gungor N, Arslanian S. Progressive beta cell failure in type 2 diabetes mellitus of youth. J Pediatr 2004;144:656-659.

7 Weiss R, Taksali SE, Tamborlane WV, Burgert TS, Savoye M, Caprio S. Predictors of changes in glucose tolerance status in obese youth. Diabetes Care 2005;28:902-909.

8 TODAY Study Group, Zeitler P, Hirst K, Pyle L, Linder B, Copeland $\mathrm{K}$, et al. A clinical trial to maintain glycemic control in youth with type 2 diabetes. N Engl J Med 2012;366:2247-2256.

9 Savoye M, Shaw M, Dziura J, Tamborlane WV, Rose P, Guandalini C, et al. Effects of a weight management program on body composition and metabolic parameters in overweight children: a randomized controlled trial. JAMA 2007;297:26972704.

10 Savoye M, Nowicka P, Shaw M, Yu S, Dziura J, Chavent G, et al. Long-term results of an obesity program in an ethnically diverse pediatric population. Pediatrics 2011;127:402-410.

Received Novmber 21, 2012 Accepted after revision November 25, 2012 